\title{
Extreme Vote Makeover: The Role of Ranked Choice Voting in the Oakland City Elections
}

\author{
Ryan M. Yonk ${ }^{1}$, Randy T. Simmons ${ }^{2} \&$ Daniel S. Groberg ${ }^{2}$ \\ ${ }^{1}$ Department of Political Science and Criminal Justice, Southern Utah University, Cedar City Ut, USA \\ ${ }^{2}$ Department of Economics and Finance, Utah State University, Logan Ut, USA \\ Correspondence: Ryan M. Yonk, Department of Political Science and Criminal Justice, Southern Utah University, \\ 351 West Univerity Blvd GC406, Cedar Ctity Utah, USA. E-mail: ryanyonk@suu.edu
}

\author{
Received: February 21, 2014 Accepted: March 4, 2014 Online Published: May 28, 2014 \\ doi:10.5539/jpl.v7n2p23 \\ URL: http://dx.doi.org/10.5539/jpl.v7n2p23
}

\begin{abstract}
This paper examines the effects that voting systems have on multicandidate elections. Using the ballot data collected from Alameda County, we have taken the votes from the recent mayoral election in Oakland City, CA, and recounted them using preference-base voting standards. After doing so we compared them to the original election outcome. The victor of this election flipped in three of the six counts these ballots underwent. This illustrates the need of the candidates of an election to understand how the differences in voting systems impact their campaign decisions.
\end{abstract}

\section{Literature Review}

The great draw of democracy is the opportunity for a person to determine how their life is governed and exercise choice. When asking his students to provide the justification for rule by democratic majority, Dennis Mueller a prominent expert in public choice and decision making, is often met by responses centered on fairness, justice, and societal egalitarianism (Mueller, 2003, p. 128). These and similar answers, however, are often given based on a lack of information regarding the potential limits placed on individual choice through various election procedures. Different voting systems within the democratic tradition, as well as the formal rules that regulate them, have a far greater impact on determining election outcomes than is typically realized (Yonk, Simmons, \& Johnson, 2010).

The variety of voting systems that exist each ideally determine the will of the people. Aggregating individual preferences is believed to produce the greatest benefit for society as a whole. This point of view, however, fails to acknowledge the collective decision-making that occurs in an election. The fundamental nature of collective choice is that some choices are made not by individuals in isolation but jointly with others. In order to make joint choices, rules must be adopted to determine how those choices will be made, and because of these rules winners and losers are chosen. But with such rules, is the will of the people truly expressed in voting? Are elections truly built to find and implement general will? (Yonk, 2010).

Marquis de Condorcet proposed the Jury Theorem as a means of selecting the best possible option in voting scenarios (Mueller, 2003, p. 129). This theorem is based on the assumption that "all citizens want the same things from their government or representative," Condorcet created a formula to portray how the larger a group becomes the more likely it is to make the most publicly beneficial voting selection. Several factors must be met for the group selection to reach the maximum amount of benefit for society. First, all citizens participating in the selection must have a probability "greater than 0.5 " in selecting the most efficient outcome. Second, these same individuals must cast their votes independently of one another (Mueller, 2003, pp. 29-30). If this were true, then voting systems would likely matter very little so long as the population was large. His formula however, is flawed in modern democratic states.

Considering these two requirements modern elections often do not meet these requirements. Citizens are largely ignorant of policy options and candidate platforms, let alone where to actually cast their votes. This situation however, does not mean these individuals should be viewed negatively. When considering the high costs of gaining that knowledge (sacrificing their time and possibly resources), and comparing it with the benefits reaped from voting. Because their individual vote likely will not determine the outcome of an election the perception is 
that these individuals are acting completely rationally. In acting rationally, however, citizens are failing to meet the requirements presented by Condorcet, bringing in to question his theory.

Similar to Condorcet, Kenneth May proposed a formula in 1952 that specified provisions that must take place if majority rule is to be effectively implemented. Relying on conditions such as decisiveness, anonymity, neutrality, and positive responsiveness, May's argument is also presented with several meaningful critiques that possibly question the formula's legitimacy (Mueller, 2003, p. 134). One of the most prominent of which brings into question his notion of neutrality that is based on the assumption that any issue voted upon must be independent (Mueller, 2003, p. 134). In order for this solution to work and result in effective majority rule, issues must be non-intermingled with other issues, which is almost never the case in modern democratic decision-making. It is almost always the case that each option is truly independent of other exogenous or endogenous forces.

The question can be posed - Why do we even need different types of voting methods? It may seem that a simple majority is what would best represent the needs and wants of all peoples involved. That can be true when dealing with an election, which decides between two candidates, as one must take the majority. But when three or more are brought into the equation it becomes difficult to get a majority consensus amongst the constituents. In fact, a simple majority could be quite impossible to reach.

It could also be argued that a plurality vote would then best be used to determine a winner. But if that is the deciding factor, a candidate in a race of multiple options could win with only a small portion of the population's approval. In a democratic society should the minority really be expressing the needs of the entire populace, and determining solutions as well? In addition to that problem, plurality rules face the issue that the existence of a third option can change the relative ranking of the first two options. That is, choices can be influenced by whether or not there are more than two candidates.

The result of having more than two options is shown by the 2002 French presidential election. The primary election consisted of three candidates: the Incumbent president Jacques Chirac, Jean-Marie Le Pen, and Lionel Jospin. President Chirac was the highest vote getter in the primary with Le Pen as the next highest and Jospin as third. Chirac and Le Pen were then placed on a ballot against each other to select the president and Chirac won. Later it was determined through polling data that in a two-person race Jospin would have defeated Le Pen and could have also defeated Chirac afterward. Hence, Le Pen's candidacy impacted the relative rankings of the candidates to the benefit of Chirac (Dasgupta \& Maskin, 2008).

From such an example we see that deciding who wins in a democratic election process is not simple. As C. L. Dodgson (Lewis Carroll), Kenneth Arrow, the Marquis de Condorcet, Duncan Black and others have argued, majority rule faces difficulties. Not the least of these difficulties is that results can be arbitrary, especially when the choice is between more than two options. If three options are offered and voters are asked to rank the three, often none of the options will be ranked first by a majority of the voters.

One possibility to overcome this is to consider the options in pairs, but then cycling can occur with each option defeating another and none of them winning. (Arrow, 1951) There are ways to end the cycling problem and legislative bodies have developed mechanism to avoid continuous cycling. (Cox \& Shepsle, 2006) But the problem is more difficult to avoid in general elections, and may well result in that common conundrum, of cycling which Condorcet described, in which A can defeat B, B can defeat C, C can defeat A.

Lastly, a problem with most voting schemes lies in their inability to effectively measure the intensity of preferences. For example, fifty-one percent of a population might have slight preferences for a candidate while forty-nine percent strongly oppose that same candidate. In this scenario the slight preferences defeat the strongly held ones. If the electoral system measured preference intensity a different candidate would be elected.

Electoral rules and systems have the potential to greatly produce arbitrary results (see, e.g. Mueller, 2003, Chapters 6 and 7). The problem with an arbitrary outcome is the importance of majority rule. "Should a democracy accept a leader who is opposed by a majority of voters? Is there anything special about a fifty percent plus one rule? Why not require supermajorities? And what about intensely held minority preferences?" (Yonk, 2010) All of this suggests that individual preferences are distorted by the workings of the basic rules of democracy. To be equitable we must remind the reader that rules can be fair in the sense that if all voters preferred $a$ to $b$, then $a$ would be selected; no one voter could influence the outcome more than any other voter; and no outcome would receive special treatment. But, these rules produce winners and losers but cannot be defended as rationally reflecting voter preferences. Any set of rules will affect voting outcomes.

Building on the work done in Trading Places, which tested these issues in the process for selecting a replacement for the Utah legislature, we undertake another test of the effects of voting rules on outcomes using 
this time the Oakland City November 2, 2010, mayoral elections. (Yonk, 2010) This paper, like Trading Places uses a real scenario and bases the hypothesis and results off actual data.

\section{The Election}

November 2010 marked a historical moment for Oakland City, California. It was the first regular election since implementation of the newly adopted Ranked Choice Voting system. Ranked Choice Voting (RCV), also called Instant Runoff Voting, was approved for use in Oakland with the passing of Measure $\mathrm{O}$ in 2006. The listed reasons for switching to this method were primarily financial as it was seen to be a more cost effective system. That savings was expected due to no primary and only one election, without later run-offs. It was also seen as an opportunity to allow more time for the candidates to fundraise and campaign, thereby increasing voter turnout. (Yes on O, 2010)

The incumbent mayor, Ronald Dellums decided not to run for re-election, leaving ten other candidates to vie for his position. As previously stated, this was the first time Ranked Choice Voting has been used in Oakland City. Of the ten candidates, City Councilwoman Jean Quan was the winner. Did she win because RCV was used? Or would she have gained the people's approval under the previously used method also? After the initial count State Senator Don Perata had the lead, but not a majority, with 33.73 percent of the vote. Quan was his closest competitor. She had 24.47 percent of the vote on that initial count. (Callahan, 2010)

With RCV each ballot has value rankings to show the preference of the voter for the selection of each candidate (in this case it was first, second, and third place). The ballots are then counted and whoever is ranked as first choice on the ballot receives that vote. The winner still needs to gain a majority of the vote, meaning fifty percent plus one. If no majority is found the candidate with the least amount of first choices is eliminated. That candidate's votes are then dispersed to the respective candidate listed as second choice on each ballot. This continues until one person has accumulated a majority of the votes. It is expected that the winner will then best represent the populace, having most likely, the most first and second choices of the voter's ballots. As Perata didn't have the majority with the first pass, votes needed to be distributed. The candidate with the least amount of first place votes was eliminated in a pass and the second choice on each ballot was added to the candidate listed there.

Perata maintained an almost nine percent lead for nine passes. In the tenth pass Jean Quan jumped to both the lead and the majority by reaching 50.96 percent of the votes. With the majority Quan was officially elected as Mayor of Oakland City. (Citation)

As stated by a journalist in the Oakland area: "Ranked-choice voting changes everything about the Oakland mayor's race: the timing, campaigning, turnout, and maybe even the winner..." (Callahan, 2010) They were correct. Using ranked choice voting changed everything about this election. The expected winner was not picked. The types of campaigning changed and the turnout was much greater than the previous elections. These rules changed the entire outcome of this election.

\subsection{Recounting the Votes}

To determine what effect Ranked Choice Voting had on the results of this election we took the ballot data and ran it through additional voting systems. Using the exact preferences given by the voters we determined how the results would have ended using the Plurality method, Borda Count, Contingent, Bucklin, and Coombs.

\subsection{Plurality}

Having already been described in this paper, the victor under the plurality method is the candidate who has the most votes; regardless as to whether or not they had a majority. Hence, in the Oakland situation there could have been a winner that had less than 20 percent of the vote. When tallying the raw first picks for each voter Don Perata came in as the winner with the most votes. He held 33.73 percent of the voter's first preference.

\begin{tabular}{|l|c|l|c|}
\hline \multicolumn{2}{|l|}{ Plurality Method } & Don Pereta & 40342 \\
\hline $\begin{array}{l}\text { Arnold } \\
\text { Fields }\end{array}$ & 733 & Jean Quan & 29266 \\
\hline $\begin{array}{l}\text { Terence } \\
\text { Candell }\end{array}$ & 2315 & $\begin{array}{l}\text { Marcie } \\
\text { Hodge }\end{array}$ & 2994 \\
\hline $\begin{array}{l}\text { Greg } \\
\text { Harryand }\end{array}$ & 966 & $\begin{array}{l}\text { "LL" Younell } \\
\text { Rebecca } \\
\text { Kaplan }\end{array}$ & 933 \\
\hline Don Macleay & 1630 & 25813 \\
\hline Joe Tuman & 14347 & Write-In & 268 \\
\hline
\end{tabular}

Figure 1. Plurality results 


\subsection{Borda Count}

Under the Borda Count voters are asked to rank in order their choices for the elected position. Points are then assigned to the rank and added together. (Emerson 2007; Reilly 2002) After all points are added the candidate with the most is considered to be the winner. In the Oakland case we had only information based on the top three choices for each voter. With that being the case, the following amounts were assigned to each rank choice: one point was assigned to rank three, two points to rank two, and three points to rank one.

With Borda applied to the Oakland election Don Perata wins again. It is done with a mere 25.53 percent of the points or 171,679. But under the rules of the Borda count that is enough. He simply needed the most.

\begin{tabular}{|c|c|c|c|c|c|}
\hline Candidate & 1st & 2nd & $3 r d$ & Total & Percent of Points \\
\hline \multirow{2}{*}{ Don Pereta } & 40293 & 18064 & 14672 & & \\
\hline & 120879 & 36128 & 14672 & 171679 & $25.53 \%$ \\
\hline \multirow{2}{*}{$\begin{array}{l}\text { Terence } \\
\text { Candell }\end{array}$} & 2308 & 3840 & 5169 & & \\
\hline & 6924 & 7680 & 5169 & 19773 & $2.94 \%$ \\
\hline \multirow{2}{*}{ Greg Harland } & 960 & 1935 & 2799 & & \\
\hline & 2880 & 3870 & 2799 & 9549 & $1.42 \%$ \\
\hline \multirow{2}{*}{ Don Macleay } & 1627 & 1884 & 2878 & & \\
\hline & 4881 & 3768 & 2878 & 11527 & $1.71 \%$ \\
\hline \multirow{2}{*}{ Jean Quan } & 29198 & 30102 & 18921 & & \\
\hline & 87594 & 60204 & 18921 & 166719 & $24.80 \%$ \\
\hline \multirow{2}{*}{ Arnold Fields } & 728 & 1594 & 2536 & & \\
\hline & 2184 & 3188 & 2536 & 7908 & $1.18 \%$ \\
\hline \multirow{2}{*}{ Joe Tuman } & 14332 & 16246 & 16654 & & \\
\hline & 42996 & 32492 & 16654 & 92142 & $13.70 \%$ \\
\hline \multirow{2}{*}{ Marcie Hodge } & 2984 & 6006 & 8575 & & \\
\hline & 8952 & 12012 & 8575 & 29539 & $4.39 \%$ \\
\hline \multirow{2}{*}{$\begin{array}{l}\text { Larry Lionell } \\
\text { "LL" Young Jr }\end{array}$} & 924 & 2154 & 3817 & & \\
\hline & 2772 & 4308 & 3817 & 10897 & $1.62 \%$ \\
\hline \multirow{2}{*}{$\begin{array}{l}\text { Rebecca } \\
\text { Kaplan }\end{array}$} & 25788 & 26333 & 19275 & & \\
\hline & 77364 & 52666 & 19275 & 149305 & $22.21 \%$ \\
\hline \multirow{2}{*}{ Write-In } & 266 & 628 & 1265 & & \\
\hline & 798 & 1256 & 1265 & 3319 & $0.49 \%$ \\
\hline
\end{tabular}

Figure 2. Borda count results

The top level with each candidate is the votes they received. The bottom consists of the points calculated from said votes. $1^{\text {st }}$ place equals three points, $2^{\text {nd }}$ equals two, and $3^{\text {rd }}$ equals one.

\subsection{Contingent}

\begin{tabular}{|c|c|c|c|c|}
\hline & Round 1 & Round 2 & Total & Percentage \\
\hline Jean Quan & 29266 & 30102 & 59368 & $50.41 \%$ \\
\hline Don Perata & 40342 & 18064 & 58406 & $46.59 \%$ \\
\hline Greg Harland & 966 & Eliminated & & \\
\hline Don Macleay & 1630 & Eliminated & & \\
\hline $\begin{array}{l}\text { Terence } \\
\text { Candell } \\
\end{array}$ & 2315 & Eliminated & & \\
\hline Arnold Fields & 733 & Eliminated & & \\
\hline Joe Tuman & 14347 & Eliminated & & \\
\hline Marcie Hodge & 2994 & Eliminated & & \\
\hline $\begin{array}{l}\text { Larry Lionell } \\
\text { "LL" Young Jr. }\end{array}$ & 933 & Eliminated & & \\
\hline $\begin{array}{l}\text { Rebecca } \\
\text { Kaplan } \\
\end{array}$ & 25813 & Eliminated & & \\
\hline Write-In & 268 & Eliminated & & \\
\hline
\end{tabular}

Figure 3. Contingent vote results 
There are only two rounds in the Contingent voting style. In the first round the first preference is the only thing taken into account. As with most methods, there needs to be an absolute majority to choose a winner. If no candidate receives a majority, the two candidates with the most votes remain for the second round and the rest are eliminated. The second place votes of those who supported the eliminated candidates are distributed between the two candidates still in the running. The candidate with the majority at this point wins the election (Rallings, Thrasher, and Cowling, 2002: 67-90). The results here were identical to those under Ranked Choice Voting. Jean Quan finished as the victor.

\subsection{Bucklin Method}

For this method voters are required to rank all candidates on the ballot. If any candidate receives an absolute majority of first place votes they win. If no majority is achieved, second choice votes are counted and added to the first choices. If no majority is to be had on this pass the process continues until the victor has a majority (Taangepera \& Shugart, 1989).

No winner was found on the first round with the Bucklin recount. Adding the second choice votes put Quan in the victor's seat with a greater majority of the vote than Perata or any other candidate.

\begin{tabular}{|c|c|c|c|c|}
\hline Candidate & 1st & 2nd & 3rd & Total \\
\hline \multirow{2}{*}{ Don Pereta } & 40293 & 18064 & 14672 & 73029 \\
\hline & $32.95 \%$ & $47.73 \%$ & $59.73 \%$ & \\
\hline \multirow{2}{*}{$\begin{array}{l}\text { Terence } \\
\text { Candell }\end{array}$} & 2308 & 3840 & 5169 & 11317 \\
\hline & $1.89 \%$ & $5.03 \%$ & $9.26 \%$ & \\
\hline \multirow{2}{*}{ Greg Harland } & 960 & 1935 & 2799 & 5694 \\
\hline & $0.79 \%$ & $2.37 \%$ & $4.66 \%$ & \\
\hline \multirow{2}{*}{ Don Macleay } & 1627 & 1884 & 2878 & 6389 \\
\hline & $1.33 \%$ & $2.87 \%$ & $5.23 \%$ & \\
\hline \multirow{2}{*}{ Jean Quan } & 29198 & 30102 & 18921 & 78221 \\
\hline & $23.88 \%$ & $48.50 \%$ & $63.98 \%$ & \\
\hline \multirow{2}{*}{ Arnold Fields } & 728 & 1594 & 2536 & 4858 \\
\hline & $0.60 \%$ & $1.90 \%$ & $3.97 \%$ & \\
\hline \multirow{2}{*}{ Joe Tuman } & 14332 & 16246 & 16654 & 47232 \\
\hline & $11.72 \%$ & $25.01 \%$ & $38.63 \%$ & \\
\hline \multirow{2}{*}{ Marcie Hodge } & 2984 & 6006 & 8575 & 17565 \\
\hline & $2.44 \%$ & $7.35 \%$ & $14.37 \%$ & \\
\hline \multirow{2}{*}{$\begin{array}{l}\text { Larry Lionell } \\
\text { "LL" Young Jr }\end{array}$} & 924 & 2154 & 3817 & 6895 \\
\hline & $0.76 \%$ & $2.52 \%$ & $5.64 \%$ & \\
\hline \multirow{2}{*}{$\begin{array}{l}\text { Rebecca } \\
\text { Kaplan }\end{array}$} & 25788 & 26333 & 19275 & 71396 \\
\hline & $21.09 \%$ & $42.63 \%$ & $58.39 \%$ & \\
\hline \multirow{2}{*}{ Write-In } & 266 & 628 & 1265 & 2159 \\
\hline & $0.22 \%$ & $0.73 \%$ & $1.77 \%$ & \\
\hline
\end{tabular}

Figure 4. Bucklin results

\subsection{Coombs Rule}

According to the Coombs Rule, voters rank every candidate on the ballot. Similar to Ranked Choice voting, the candidate with the majority wins. If that is determined on the initial count the entire process goes much faster (Grofman and Feld, 2004: 641-659). But if a winner is not determined in the first round, the eliminated candidate is the one who receives the most last place votes. Note, with this method it is the candidate with the most last place votes and not the Instant Runoff method of removing the candidate with the least first place votes. The process is repeated, multiple times if necessary. The pool of hopefuls continuously reduces until one candidate obtains a majority of first place votes and wins.

The preferred way to run this method is to have a ranking system to account for all candidates. Hence, in the Oakland scenario the best way to handle ranking would be to provide rankings from one to ten, there being ten candidates. But this election was run with a ranking of three positions. With the restrictions on the Coombs Rule being such, we ran the data using third place as the eliminating factor, it being the closest available to the last choice.

Following this method, Rebecca Kaplain was the first eliminated, followed by Jean Quan and Don Perata respectively. At this point in time there are no candidates who come even close to getting a majority of the vote if we use the original amount of votes to compute candidate percentages. But if we use the decreasing amount of 
base votes as the denominator (decreasing occurring from ballots becoming exhausted) then we do reach a majority with of the votes with Don Perata. Following this method, with these restrictions puts Perata as the winner of the election.

\begin{tabular}{|c|c|c|c|c|}
\hline \multicolumn{2}{|c|}{ Round 3 Results } & Ist Choice & 2nd Choice & 3rd Choice \\
\hline $\begin{array}{l}\text { Overvote/ } \\
\text { Exhausted }\end{array}$ & & 12094 & 16680 & 64845 \\
\hline Write-In & & 610 & 818 & 3420 \\
\hline Don Perata & & 57404 & 10538 & 31068 \\
\hline $\begin{array}{l}\text { Terence } \\
\text { Candell } \\
\end{array}$ & & 4313 & 4870 & 13707 \\
\hline Greg Harland & & 2314 & 1762 & 7497 \\
\hline Don Macleay & & 3515 & 1348 & 6600 \\
\hline Jean Quan & Eliminated & & & \\
\hline Arnold Fields & & 1801 & 1662 & 6678 \\
\hline Joe Tuman & Eliminated & & & \\
\hline Marcie Hodge & & 7186 & 6274 & 21726 \\
\hline $\begin{array}{l}\text { Larry Lionell } \\
\text { "LL" Young Jr. }\end{array}$ & & 2220 & 2610 & 10110 \\
\hline $\begin{array}{l}\text { Rebecca } \\
\text { Kaplan } \\
\end{array}$ & Eliminated & & & \\
\hline
\end{tabular}

Figure 5. Coombs results

\subsection{Summary of Recounts}

This race was essentially held between two candidates. City Councilwoman Jean Quan and State Senator Don Perata. Including the initial Ranked Choice Voting count, these ballots have been run through six different kinds of voting methods. The now Mayor Quan wins in three methods and Perata wins in the other three.

\begin{tabular}{|l|l|l|}
\hline \multicolumn{3}{|c|}{ Electoral Outcomes by Voting } \\
\hline \multirow{2}{|c|}{ Rethod } \\
\hline Ranked Choice Voting & 1st & 2nd \\
Contingent & Quan & Perata \\
Bucklin & Perata \\
Plurality & Quan & Perata \\
Borda & Perata & Quan \\
Coombs & Perata & Quan \\
\hline
\end{tabular}

Figure 6. Summary of recounts

\subsection{Reflecting Preferences}

Voter preferences are reflected differently by the various voting methods. Hence, the change in election results. Perata was the plurality winner, and it was expected for much of the voting process that he would win the actual election. Yet, according to news media in the area he was more of a polarizing figure, making his second and third choices less frequent than Quan. Quan won under all other voting rules because she received more second place votes than any other candidate by a large margin. There is great change in the outcomes of these voting methods as half of those tested would have produced a different winner.

\section{Discussion}

Voting and counting rules matter very much in an election. Oakland City proves this. It should be noted that voting methods also alter campaigning. A polarizing character, such as Perata, that tends to either have loyal followers or stark opponents does not have as well of a chance as a more moderate candidate who is maybe not adored by anyone but generally liked by all. In RCV the second choice pick is one of the most important stations 
to have access to. It was reported that Quan encouraged voters to put her first, but even if she wasn't their first choice that they should still have her down as their second. She also made an agreement with Rebecca Kaplan, who landed in $3^{\text {rd }}$ place overall. Their agreement was that they would encourage their supporters to put the other as the second choice on their ballots. (Callahan, 2010)

Perata did have more people vote with him as their first choice. But Quan's agreement with Kaplan turned out to be the breaker in this election. When Rebecca Kaplan was eliminated in the tenth and final pass a great majority of her votes went to Quan. This propelled Quan to the Mayor's seat.

The findings from this case study are consistent with Trading Places and Brams, Hansen, and Olsen (2006) who showed that different multicandidate preference voting systems result in varied outcomes. Brams et al. used their ballots from the 2006 Public Choice Society Presidential election.

In their case the Brams et al. were able to calculate a Condorcet, Plurality, Borda count, and IRV method. Their ability to do so stemmed from asking their voters to rank their voting choices. Though these rankings did not effect the placement of the candidates it provided the ranking data needed to run these ballots through the other four voting systems. Out of the five candidates running, there were two different winners depending on which of the four voting standards were used. It is interesting to note that none of them were the winner chosen in the original Approval Voting method.

In our case, the Oakland election was frankly dominated by the two main characters of Jean Quan and Don Perata. Quan was trailing by approximately 9 percent of the vote for nine passes. But when Rebecca Kaplan was eliminated in pass ten Quan received 18,864 of Kaplan's 32,719 votes. Perata received 6,407 of said votes. The remaining votes were exhausted and unusable. This dramatic influx of votes catapulted Quan forward and gave her 50.96 percent of the votes with the amount of 53,897. By examining the data, it is not far off to say that the difference in the voting required for most of the other candidates to win instead is next to impossible.

Perata has a chance of winning. If 1,013 more votes had gone to him rather than Quan in the final pass then his margin of the vote would have been 52,885 and he would have one vote over 50 percent. It appears that pursuing additional second choice ranking would have been the most logical push for him to take. It is much more difficult to get first place choices over second. In addition, second choice has proven in this election to be the determining factor. Quan was launched forward nearly ten percent in a single pass because of it.

As expected with the changes made to this election there were those who were not happy with the new type of voting. Most of the vocal opposition to Ranked Choice voting came from those candidates who had lost. They complained that things were not set out clearly and that it was not run the way an election usually is. They were right. The change in vote system rules changed everything about this election. (PBS, 2010)

\section{Conclusion}

What was learned from the Oakland election? Did this vote truly reflect the will of the people? The object here is not to discredit the victory of Jean Quan, but to address the fact that voting systems matter. Oakland City's mayoral election and the way in which candidates trade places, indicates that they do. If the administrator of an election understands voter preferences an election can be presented in such a way, or such an order that the winner is not decided by the people's greater voice, but in reaction to the desires of said administrator.

As we have previously found in Trading Places "elections will be held even though theorists understand that the election results are structured by voting and counting rules. After all, democratic politics is about voters choosing between alternatives, not about discovering the "General Will."

\section{References}

Black, D. (1971). The Theory of Committees and Elections. Cambridge: Cambridge University Press.

Brams, S. J. (1985). Rational politics: Decisions, games, and strategy. Washington, D.C.: CQ Press.

Brams, S. J., \& Hansen, M. W., \& Orrison, M. E. (2006). Dead Heat: The 2006 Public Choice Society Election. Public Choice, 128, 361-366. http://dx.doi.org/10.1007/s11127-006-9060-x

Brams, S. J., \& Sanver, M. R. (2006). Critical Strategies Under Approval Voting: Who Gets Ruled in and Ruled Out. Electoral Studies, 25, 287-305. http://dx.doi.org/10.1016/j.electstud.2005.05.007

Callahan, L. (2010). How will ranked-choice voting change Oakland election? Oakland North.

Cox, G. W. (1997). Making Votes Count: Strategic Coordination in the World's Electoral Systems. Cambridge, U.K.: Cambridge University Press. http://dx.doi.org/10.1017/CBO9781139174954 
Cox, G. W., \& Shepsle, K. A. (2006). Majority Cycling and Agenda Manipulation: Richard McKelvey's Contributions and Legacy. In J. Aldrich, J. E. Alt, \& A. Lupia (Eds.), A Positive Change in Political Science: The Legacy of Richard McKelvey's Most Influential Writings. Ann Arbor: University of Michigan Press.

Dasgupta, P., \& Maskin, E. (2008). On the Robustness of Majority Rule. Journal of the European Economic Association. http://dx.doi.org/10.1162/JEEA.2008.6.5.949

Diamond, L., \& Plattner, M. F. (2006). Electoral Systems and Democracy. Baltimore: The Johns Hopkins University Press.

Emerson, P. (2007). Designing an All-Inclusive Democracy. Belfast, Northern Ireland: Springer. http://dx.doi.org/10.1007/978-3-540-33164-3

Farrell, D. M. (1997). Comparing Electoral Systems. London: Prentice Hall.

Farrell, D. M. (2001). Electoral Systems: A Comparative Introduction. New York: Palgrave.

Gallagher, M., \& Marsh, M. (1988). Candidate Selection in Comparative Perspective: The Secret Garden of Politics. London: Sage.

Grofman, B., \& Feld, S. L. (2004). If You Like the Alternative Vote, Then You Ought to Know About Coombs Rule. Electoral Studies, 23, 641-659. http://dx.doi.org/10.1016/j.electstud.2003.08.001

Katz, R. S. (1980). A Theory of Parties and Electoral Systems. Baltimore: The Johns Hopkins University Press.

Keating, D. (2002). Democracy Counts: The Media Consortium Florida Ballot Review. Paper presented at the annual meeting of the American Political Science Association, Boston Marriott Copley Place, Sheraton Boston \& Hynes Convention Center, Boston, Massachusetts. Retrieved June 10, 2008, from http://www.allacademic.com/meta/p66142_index.html

Lijphart, A. (1999). Patterns of Democracy: Government Forms and Performances in Thirty-Six Countries. New Haven: Yale University Press.

Lijphart, A., \& Grofman, B. (1986). Electoral Laws and Their Political Consequences. New York: Agathon Press.

Marsh, M. (1985). The Voters Decide?: Preferential Voting in European List Systems. European Journal of Political Science, 13(4), 365-378. http://dx.doi.org/10.1111/j.1475-6765.1985.tb00132.x

Mueller, D. C. (2003). Public Choice III. Cambridge: Cambridge University Press. http://dx.doi.org/10.1017/CBO9780511813771

Norris, P. (2004). Electoral Engineering: Voting Rules and Political Behavior. Cambridge: Cambridge University Press. http://dx.doi.org/10.1017/CBO9780511790980

PBS News Hour. (2010). Oakland Election System Allows Mayoral Runner-Up to Make a Surprise Win. Retrieved November 19, 2010, from http://www.pbs.org/newshour/bb/politics/july-dec10/oakland_11-19. $\mathrm{html}$

Rae, D. W. (2007). The Political Consequences of Electoral Laws. New Haven: Yale University Press.

Rallings, C., Thrasher, M., \& Cowling, D. (2002). Mayoral Referendums and Elections. Local Government Studies, 28, 67-90. http://dx.doi.org/10.1080/714004163

Registrar of Voters. (2011). Macdonald, Dave. Ranked-Choice Voting. Retrieved April 6, 2011, from http://www.acgov.org/rov/rcv/results/rcvresults_2984.htm

Reilly, B. (2002). Social Choice in the South Seas: Electoral Innovation and the Borda Count in the Pacific Island Countries. International Political Science Review, 23, 355-372.

Reynolds, A., \& Reilly, B. (1997). The International IDEA Handbook of Electoral System Design. Stockholm: International Institute for Democracy and Electoral Assistance.

Richie, R., Hill, S., \& Kleppner, C. (2002). Instant Runoff Voting and Full Representation: Keys to Fulfilling Democracy's Promise. In Democracy's Moment (pp. 143-157). Lanham, MD: Rowman and Littlefield. http://dx.doi.org/10.1177/0192512102023004002

Taagepera, R., \& Shugart, M. S. (1989). Seats and Votes: The Effects and Determinants of Electoral Systems. New Haven: Yale University Press.

Villodres, C. O. (2004). Position Effects under STV: Ireland and Malta. Representation (McDougall Trust), 41. 
Yes on O. (2011). Bringing Instant Runoff to Oakland. Retrieved April 6, 2011, from http://archive.fairvote.org/oaklandirv/webarchive/

Yonk, R., Simmons, R. T., \& Johnson, D. (2010). Trading Places: The Effects of Voting Systems on Multicandidate Elections. Public Choice.

\section{Copyrights}

Copyright for this article is retained by the author(s), with first publication rights granted to the journal.

This is an open-access article distributed under the terms and conditions of the Creative Commons Attribution license (http://creativecommons.org/licenses/by/3.0/). 